\title{
Improvement of the Effectiveness of Ideological and Political Education in Higher Vocational Colleges by Means of Self-media
}

\author{
Wenqi Zhu \\ Qingdao Ocean Shipping Mariners College, Qingdao City, Shandong Province, 266071, China
}

Keywords: self-media; higher vocational colleges; ideological and political education; effectiveness

\begin{abstract}
With the popularization of the Internet and the continuous development of the new media such as blog, forum and microblog, a self-media era has arrived. As the educational object of ideological and political education in higher vocational colleges, college students are also important parts of self-media audiences. At present, there are some problems in ideological and political education in higher vocational colleges, which affect the effectiveness of ideological and political education. In order to enhance the effectiveness of ideological and political education in higher vocational colleges, we have studied it by means of self-media. In this paper, based on the authors' learning and work experience, we first analyzed the characteristics of the self-media, and then discussed the challenge of ideological and political education in higher vocational colleges under the self-media environment. Finally, we put forward implementation paths of improving the effectiveness of ideological and political education in higher vocational colleges by means of self-media.
\end{abstract}

\section{Introduction}

Ideological and political work is the lifeline of economic work and all other work. Ideological and political education, the central part and basic content in ideological and political work, is a unique educational activities, which already exists in all aspects of life. With the rapid development of social economy and the gradual popularization of scientific and technological achievements, The colleges have faced unprecedented opportunities and challenges of cultivating the builders and successors of socialist modernization. Especially, the arrival of self-media represented by the blogger and microblog makes the enhancement of the effectiveness of the ideological and political education in higher vocational colleges be a problem needed to be urgently solved.

\section{The Interpretation of Self-media Features}

Self-media, a new type of information technology achievement based on WEB2.0, has characteristics of a wide range of communication content, multi-dimensional communication channels, open communication dimension, and diversified communication means, which make the past closed media ecological environment dominated by the government and media institutions evolved into open and increasingly mature one where "everyone is a journalist". It is because every netizen can act as a reporter of news events that some netizens who do not have the basic media literacy, or are out of herd mentality, make the self-media faced with the issues such as lagging management and public audiovisual confusion. As the future builder and successor of the socialism cause, college students are vibrant and courageous in facing the challenges from the new things.

With the continuous improvement of individual consciousness, the eagerness of sending out college students' own voice become their active pursuit in the process of growth. The self-media conforms to the development of this tide. College students can freely express their emotions, and speak out on account of some social issues through the network media forms such as blog, microblog, online community, forum and BBS. Colleges are platforms of cultivating the growth and progress of the college students. How to carry out the ideological and political education disciplines construction and the schools' ideological and political work to conform to the development trend of the self-media 
era, and how to use the campus mainstream network public opinion to guide a variety of network subculture development in self-media era need to well apply the development of self-media into the various work of college ideological and political education to enhance the effectiveness of college ideological and political education.

\section{Challenges Faced by Ideological and Political Education in Higher Vocational Colleges under the Self-media Environment}

The traditional ideological and political education mode gradually gets cold reception. With the arrival of the self-media era, the information dissemination gradually modernizes and automates. The information content with the impact on students' ideology obtained from the self-media such as forum, post bar, microblog and WeChat is far beyond the content required by ideological and political education in higher vocational colleges. The original one-way ideological and political education relationship begins to interact with each other to develop. The advantages of the traditional preaching and indoctrination education mode gradually disappears under the impact of the self-media.

The status advantage of ideological and political educators is weakening. In the era of asymmetric knowledge information of teachers and students, the image of knowledgeable teacher is relatively easy to be convinced and admired by the students. However, under current self-media environment, the students' information and knowledge acquisition is no longer a single channel, and not limited by the time and region. In this revolution era, China's various thoughts spring up, and the network is filled with many views. How to hold and consolidate ideological and political educators' rights to speak in the noisy environment is also an important problem regarding the effectiveness of ideological and political education.

The ideological and political education content needs to be integrated. Ideological and political education is not a simple knowledge impartment, but the formation of values and the realization of human free and comprehensive development with the help of knowledge impartment. However, the ideological and political education in higher vocational colleges has mainly made the students to achieve this purpose via knowledge impartment, emphasized the study and memory of Marxist theoretical knowledge, and ignored actual needs of the social development and human growth. After the reform and opening up, ideological and political education takes the attitudes of avoiding discussion or avoiding the important and dwelling on the trivial on a lot of ideological and practical problems appeared in the process of economic and social development, and the social hot spots, difficulties and doubts concerned by the people, and fails to conduct the timely correct theoretical guidance and interpretation. With the arrival of self-media, the network transmission pattern is more efficient, and the dissemination content is very complicated.

The effect of the new carrier of ideological and political education is insufficient. Under the condition of the new era, the self-media becomes the latest ideology "fighting field". In the face of the new environment, many higher vocational colleges actively respond and take the initiative to expand the position of ideological and political education to the virtual world of the mobile Internet, and achieved certain achievements. Suffered from the influence of the common thinking mode of traditional ideological and political education, and the limitation of the quality of the educators, the ideological and political education function of the official self-media such as microblog and WeChat of higher vocational colleges has not been fully excavated, and needs to be effectively guided. For example, many higher vocational colleges, especially the local colleges with relatively closed information and conservative thoughts, have not applied and registered the subscription-based official self-media public platform in the name of the school officials. 


\section{The Way to Enhance the Effectiveness of Ideological and Political Education in Higher Vocational Colleges under the Self-media Environment}

Adhere to the "students-oriented" educational philosophy. "If an ideological education cannot be included in the recipient's inherent needs, it is difficult for the recipient to accept. The ignorance of recipient's inherent needs is easy to produce the inherent barriers among the recipients, and enlarge the psychological distance." Therefore, to improve the effectiveness of ideological and political education, the first concern should be placed on students' needs, and the "students-oriented" educational philosophy should be adhered to. Under the self-media environment where the college students' autonomy has been enhanced, on the one hand, we should listen to students' voices, collect students' opinions, take the initiative to join in college students' habits and the familiar network platform, make the use of the advantages of strong interaction of the self-media, and understand their real needs for educational activities. On the other hand, we should respect and guide the autonomy of college students, give the greatest degree of satisfaction to the correct demands, and give the necessary timely guidance to the wrong demands. Ideological and political education is to seek for the innovation from the content on the basis of the profound analysis and grasp of this demand, constantly stimulate the sustained growth of ideological and political education needs sensitivity to form a strong educational drive and educational consciousness, bring the minds' touch and ideological resonance to the recipient, and become an action guidance.

Enhance the comprehensive quality of ideological and political educator. Modern network technology not only accelerates the knowledge-updating speed, but also improves the thoughts-spreading freedom. Many changes will undoubtedly put forward higher demands on the knowledge structure and ability of the ideological and political educators, and it is impossible to win the favor of the students who are good at using the self-media only via a textbook or a handout. In the face of students' information access diversification and values pluralism, the teachers engaged in ideological and political education first need to keep the political bottom line. The essence of ideological and political education lies in the reproduction of political values which point to the development of ideological and political qualities of the educatee. This requires the educators always upholding the political spirit and political requirements, firmly grasping the leadership and the right to speak of the ideological and political education work, and constantly consolidating the guiding position of Marxism. Second, the ideological height needs to be constantly enhanced. Ideological and political education aims at achieving the purpose of ideological transformation. Under the self-media environment, a variety of ideological trends spring up, and a variety of views confront with each other. The students need no longer how much knowledge that the teachers have imparted, but how much truth that they have clarified. These principles should not only have a certain ideological height, but also be consistent with common sense, logic and the truth. Third, we need to master the network technology, consciously adapt to the requirements of the self-media era, timely updates and supplement knowledge and information, cultivate information sensitivity, improve personal media literacy, correctly access, interpret and judge the various information on the Internet, timely release the information on the our self-media platforms such as WeChat and microblog, communicate and interact with the students at any time, and play a role of active guidance.

Enhance the media literacy of ideological and political educatee. The rapid development of the self-media not only greatly expands students' awareness and vision, but also causes information pollution and explosion, which affects students' information control and judgment, and physical and mental health. As early as 1933, the British scholar Levi and his student Thompson co-published the "culture and environment: cultivating the critical consciousness", which first made a systematic exposition on the introduction of media literacy education system into the schools, and proposed a series of recommendations. Its purpose is to cultivate students' media criticism awareness so that they can consciously resist the adverse effects of the mass media through the media literacy education. China's media literacy education started relatively late, which so far still did not receive enough attention in higher vocational colleges. College students' media literacy needs to be urgently 
improved. Therefore, the college ideological and political education should actively open up this new field, incorporate new contents, properly assume the work of college students' media literacy training, help the students to establish the ability to deal with the information by themselves, and consciously sort, screen and reorganize network information. Only if college students have this kind of comprehensive ability of information interpretation, criticism and utilization, will they not blindly believe in all kinds of information on the self-media platform, can they both enter the network and step out of the network, and become the owner of the self-media.

\section{Summary}

With the rapid development of the economy, the great emergence of pluralistic values has an increasingly large ideological impact on the students in higher vocational colleges under the influence of globalization. How to improve college students' ability to judge multiple standards, and establish the correct values, especially in the era of rapid development of self-media and information explosion, is a realistic problem in the ideological and political work of higher vocational colleges in China. Higher vocational colleges should fully understand the importance of this issue, gradually form an effective ideological and political education system, and thus cultivate a new generation of innovative talents with comprehensive development.

\section{References}

[1] BAO Xue. Research on the effectiveness of ideological and political education in higher vocational colleges under the environment of the new media [J]. Contemporary Education Practice and Teaching Research, 2016, (12): 20.

[2] WU Yuying. Analysis of the effectiveness of ideological and political education in universities under the new media environment [J] New Heart (Early of Middle), 2015, (12): 29.

[3] LI Rui. Analysis of remodeling paths of college ideological and political education discourse rights in the self-media era [J] .Journal of Taiyuan City Vocational and Technical College, 2015, (04): 45-46.

[4] YANG Yindan, LI Wenlu, HE Yakun. Research on the effectiveness of college ideological and political education [J]. Theories, 2014, (17): 270-271 + 286.

[5] WANG Dapeng. New ideas of college ideological and political education at the self-media era [J]. Oriental Enterprise Culture, 2014, (11): $11+14$.

[6] ZHANG Xiaohong. Study on the effectiveness of college ideological and political education [J]. Theories, 2011, (35): 266-267.

[7] ZHAO Junfeng. Research on the effectiveness of ideological and political education of college instructor [J]. Journal of North China Electric Power University (Social Science Edition), 2009, (03): 133-137. 